\title{
КОМПРЕССИОННАЯ ТЕХНОЛОГИЯ ИЗГОТОВЛЕНИЯ СЬЕМНЫХ АКРИЛОВЫХ ЗУБНЫХ ПРОТЕЗОВ ПОСРЕДСТВОМ ПРИМЕНЕНИЯ КЮВЕТЫ ДВОЙНОГО ВИНТОВОГО ДОЖАТИЯ
}

\author{
Чижсв Ю.В., Радкевич А.А., Маскадынов Л.Е., Казанцева Т.В.
}

Цель: разработка метода изготовления съёмных зубных протезов компрессионным способом в латунных классических кюветах с получением разъемной пресс формы (итамп +контрштамп) без существенного удорожания себестоимости конечного продукта с применением кювет двойного винтового дожатия.

Материалы и методы. Описана разработанная конструкция кюветы двойного винтового дожатия, технология изготовления съемных пластмассовых зубных протезов с ее использованием. Содержание остаточного мономера в стоматологической пластмассе осуществляли методом экстракции. Использовали образиы стоматологических базисных акриловых пластмасс: протакрил, вертекс, бесиветная, этакрил и фторакс в виде брусков. Образиы получали серийно в кювете двойного винтового дожатия с одинаковыми условиями полимеризации. Методом спектрофотометрии определяли количество остаточного мономера через 5, 10, 17, 19, 22 суток в каждой пробе. Пористость вымеуказанных образиов изучали путем электронно-микроскопического сканирования сколотых поверхностей, напыленых платиной в установке вакуумного магнетронного напыления K575XD.

Результаты. Установлено, что содержание остаточного количества мономера в образцах, изготовленных с помощью кюветы двойного винтового дожатия, было меньше, в сравнении с традиционными технологиями, в «протакриле» в 10 раз, «вертексе» - в 7 раз, бесиветной пластмассе - в 2 раза, «этакриле» и «фтораксе»-в 4 раза. Пористость основной поверхности для пластмасс «вертекс», «протакрил», «фторакс» и «этакрил» не превышала тысячных долей процента, исключение составила бесиветная пластмасса, имеющая относительно высокую пористость $-3,9 \%$. 
Заключение. Предложенная кювета двойного винтового дожатия позволяет сохранять заданные размеры (вследствие отсутствия грата), значительно уменьшить токсичность и пористость пластмасс и, как следствие, повысить прочностные свойства изготавливаемых протезов.

Ключевые слова: съемный пластиночный протез; кювета; компрессионный способ; винтовое дожатие.

\title{
THE COMPRESSION TECHNOLOGY OF MANUFACTURING OF REMOVABLE ACRYLIC DENTURES THROUGH THE USE OF THE CUVETTE OF DOUBLE SCREW COMPRESSING
}

\author{
Chizhov Yu.V., Radkevich A.A., Maskadynov L.E., Kazantseva T.V.
}

Purpose. To develop a method of manufacturing removable dentures compression method in brass classic cuvettes to obtain a connector mold press (stamp +counter-stamp) without a significant rise in the cost of the final product with the use of cuvettes double screw-press.

Materials and methods. The developed design of the cuvette of double screw compression, the technology of manufacturing removable plastic dentures with its use is described. The content of residual monomer in dental plastic was carried out by extraction. Using samples of dental base acrylic resin: protakril, verteks, colorless, etakril and ftoraks in the form of bars. The samples were serially obtained in a cuvette of double screw compression with the same polymerization conditions. A spectrophotometry method was determined amount of residual monomer using 5, 10, 17, 19, 22 days in each sample. The porosity of the above samples was studied by electron microscopic scanning of cleaved surfaces sprayed with platinum in a vacuum magnetron sputtering unit K575XD.

Results. The content of residual quantities of mo-rooms in the samples made using the cuvette of double screw to gate, was less in comparison with traditional technologies, "protec-Rila" 10 times, "the vertex" - 7 times, colorless plastic - 2 times, "the etakril and ftoraks" - 4 times. The porosity of the main surface for plastics "vertex", "protakril", "ftorax" and "etakril" did not exceed one thousandths of a percent, the exception was colorless plastic, which has a relatively high porosity $-3.9 \%$. 
Conclusion. The proposed cuvette of double screw compression allows to maintain the specified dimensions (due to the absence of grate), significantly reduce the toxicity and porosity of plastics and, as a consequence, increase the strength properties of manufactured prostheses.

Keywords: removable plastinochny artificial limb; ditch; compression way; screw dozhaty.

\section{Введение}

В зубном протезировании можно выделить технологическую, биологическую и финансовую составляющие.

Технологическая составляющая осуществляется в большинстве случаев согласно разработкам 50-70 годов прошлого столетия с применением акриловых базисных пластмасс горячего отверждения (этакрил, фторакс, бесцветная пластмасса и др.) или самотвердеющих (протакрил, протакрил-м, редонт и др.).

Необходимость совершенствования этих технологий обусловлена недостаточностью прочностных характеристик получаемых зубных протезов, что ведет к необходимости выполнения починок в виду частых поломок данных конструкций [2-6].

Биологическая составляющая. Анализ состояния полости рта у больных, использующих съемные протезы, базис которых изготовлен из акриловых пластмасс, особенно с починками быстротвердеющими пластмассами, позволяет утверждать, что указанные пластмассы нередко вызывают воспалительные изменения в слизистой оболочке протезного ложа. Их определяют в клинике как акриловый, или «протезный стоматит». Причиной воспалительных изменений в большинстве случаев являются повторные выделения мономера из базисов протезов и его токсико-аллергическое местное и общее воздействие на организм. Поэтому и с биологической позиции актуальной является разработка способов, позволяющих уменьшить содержание мономера в базисах протезов [1, 7-9].

Финансовая составляющая. В связи с тем, что данные технологии изготовления съемных протезов являются простыми в применении, не дорогостоящими и освоены практически повсюду на территории Российской Федерации, именно эти технологии и базисные пластмассы допущены к применению в системе ОМС (т.е. позволяют получение протезов льготно, бесплатно или путем частичной оплаты пациентами) [9-17].

Не вызывает сомнения тот факт, что в период открытых границ новые, более эффективные иностранные технологии изготовления съемных 
протезов были освоены отечественными специалистами, особенно в частном секторе. Однако стоимость таких протезов, как правило, в несколько раз выше. В этой связи такие протезы, изготовленные с применением прогрессивных технологий, с использованием «супер» пластмасс, в условиях современного экономического развития недоступны большей части населения нашей страны, в особенности лицам пожилого и старческого возраста.

На основании изложенного, в том числе с позиций импортозамещения и финансовой целесообразности, разработка новых эффективных методов изготовления зубных протезов с применением акриловых пластмасс остается актуальной.

Цель работы: разработка метода изготовления съёмных зубных протезов компрессионным способом в латунных классических кюветах с получением разъемной пресс формы (штамп+контрштамп) без существенного удорожания себестоимости конечного продукта с применением кювет двойного винтового дожатия.

\section{Материалы и методы исследования}

Недостатки традиционного компрессионного прессования в разъемной пресс-форме. Получение разъёмной гипсовой пресс-формы с использованием классических латунных кювет (обратный способ компрессионного прессования) (рис. 1) следует отнести к классическому методу, при котором применяют два замешивания гипса с необходимым интервалом между ними. Такой метод замены воска на пластмассу получил в специальной литературе название компрессионного прессования. К его принципиальным недостаткам следует отнести то, что в процессе формовки излишки (грат) полимер-мономерной композиции удаляются (выдавливаются) по линии разъема половин кюветы и создаются предпосылки к увеличению толщины базиса протеза (рис. 2).

Степень этого увеличения равна толщине слоя пластмассы между половинами гипсовой пресс-формы. Кроме того, на эту же величину происходит вертикальное перемещение искусственных зубов относительно протетической плоскости. Анализ технологии изготовления большинства съемных протезов даёт основание утверждать, что компрессионное прессование является причиной изменения формы протеза, снижения прочностных свойств, образования внутренних пор (пустот) и повышению содержания мономера. Компрессионное прессование имеет существенные технологические недостатки, которые особенно отрицательно проявляются в процессе замены воска на пластмассу. 


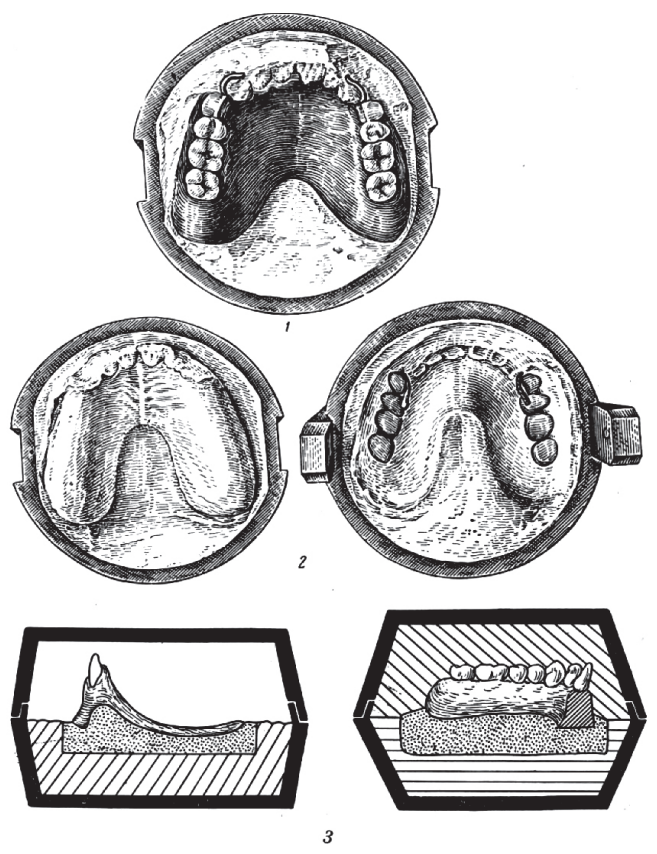

Рис. 1. Гипсование в классической латунной кювете обратным способом. 1 - модель с восковым шаблоном и зубами в кювете; 2 - кювета в раскрытом виде после удаления воска; 3 - схематическое изображение

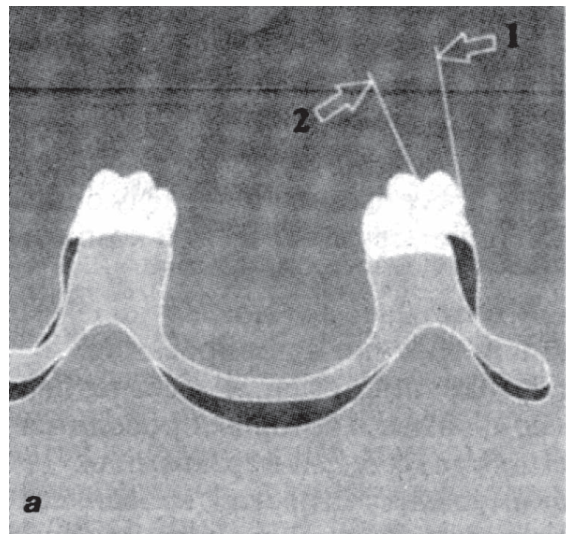

Рис. 2. Сравнение объемных изменений пластмасс при компрессионном прессовании 
При этом по окончании формирования на базисный материал, находящийся в форме, давление не оказывается. Поэтому не представляется возможным уплотнить пластмассу, чтобы уменьшить её усадку при полимеризации и исключить возникновение пустых пространств. Во время сближения штампа и контрштампа излишки пластмассы вытесняются между ними и препятствуют их соприкосновению. Образуется грат. Для изменения слоя грата в промышленности штампы и контрштампы изготавливают из твёрдых сплавов и применяют высокое давление. Гипс - материал не прочный и создать с его помощью большое давление невозможно, т.к. неизбежно разрушение формы и увеличение слоя грата. Грат, образующийся при обратной гипсовке протезов, в кювете приводит к завышению высоты и утолщению базиса протеза с оральной стороны, т.к. искусственные зубы, находящиеся в контрштампе, образно говоря, не возвращаются на прежний уровень, а остаются в ином положении, напрямую зависящем от толщины грата. В этой связи кламмеры также оказываются смещёнными, если они были при загипсовке переведены в контрштамп. Согласно данным литературы, при фиксации протезов в ротовой полости на коррекцию окклюзионной поверхности пластмассовых зубов в частичном съемном протезе с 7 и более зубами врач затрачивает около 20 минут [10-12].

Критически оценивая метод формовки базисного материала путём компрессионного прессования, можно сделать вывод о том, что в технологию компрессионного прессования в классических латунных кюветах заложена неизбежность изменения формы протеза.

Недостатки литьевого прессования.

Получение неразъёмной гипсовой пресс-формы.

Данный метод требует применения специальной (нестандартной) кюветы. Для этого на гипсовой модели с восковым базисом и искусственными зубами создается литниковая система из специальных сортов воска, а гипсовка в кювету проводится одним замешиванием гипса или силиконовой массы.

После удаления воска такая пресс-форма не может быть визуально проверена на предмет полного и качественного его удаления. Формовка полимер-мономерной композиции проводится при более жидкотекучем состоянии массы через систему литников под давлением, создаваемым специальным поршнем (принцип «шприца»). Такой способ замены воска на пластмассу получил название метод инжекционно-литьевого прессования (рис. 3). 


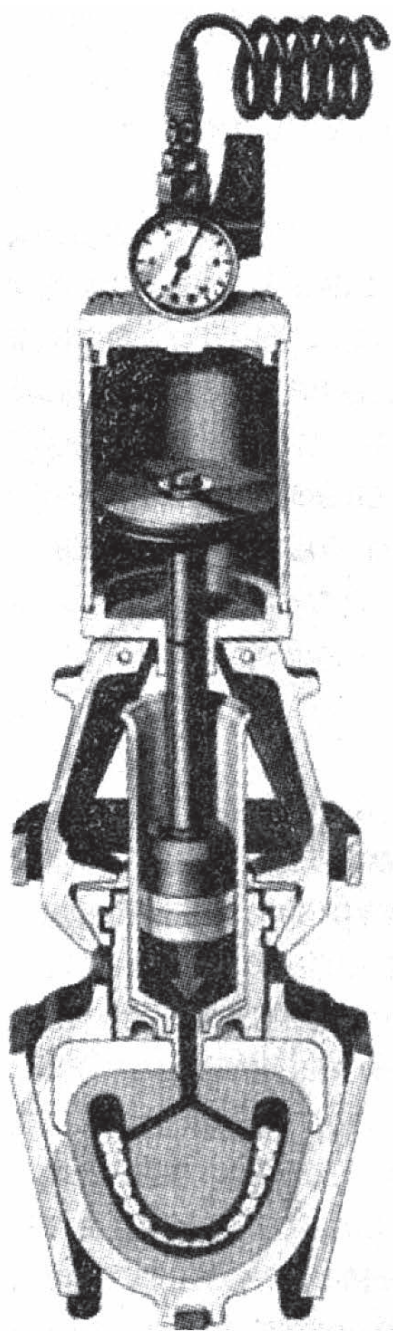

Рис. 3.

Метод инжекционнолитьевого прессования пластмассы.
Поршень инжектора во время полимеризации находится под сжимающим действием пружины, поэтому из него в полость гипсовой пресс-формы через литник поступает дополнительное количество формовочной массы, компенсирующее полимеризационную усадку. При этом методе прессования (формовки) отсутствуют линейно-объемные вертикальные изменения базиса, которые имеют место при компрессионном прессовании, содержание остаточного мономера не превышает 0,2$0,5 \%$, незначительные упругие внутренние напряжения, до минимума исключено коробление базиса, за счет чего последний близко соответствует рельефу протезного ложа.

Несмотря на указанные факты, следует отметить и недостатки: отсутствие визуального контроля полноты удаления воска из гипсовой пресс-формы, проблематичное нанесение изоляции на стенки гипсовой пресс-формы, что проявляется или в недостаточно прочном химическом соединении искусственных зубов и пластмассы базиса, или в искажении рельефа базиса.

Известно, что гипс, обладая пористой структурой, не препятствует проникновению мономера в его толщу. Если поверхность гипса при производстве протеза не изолировать от набухшей пластмассы, то часть мономера внедряется в поверхностный слой гипса и там полимеризуется. Механическое удаление этого слоя с внутренней поверхности базиса протеза ведет к искажению его рельефа, ухудшает фиксацию протеза и адаптацию к нему. Грубая шероховатость в виде пор различной величины, бугров, шипов, острых гребней, неровностей встречается на внутренней поверхности 25-74\% пластиночных протезов. 
Возникновение мелких поверхностных пор связано с гигроскопичностью гипсовых моделей, крупных пор - с испарением мономера при быстром повышении температуры во время полимеризации, эрозий на поверхности базисов протезов - с испарением воды, а бугорки, гребешки, неровности и шипы образуются вследствие вдавления пластмассового теста в поры гипсовых моделей.

В целях устранения вышеперечисленных недостатков съемного зубного протезирования разработана технология изготовления съемных акриловых протезов компрессионным способом [разъемная пресс-форма (штамп+контрштамп)] посредством применения кюветы двойного винтового дожатия.

Задачей данной разработки явилось создание простой в изготовлении, дешевой и удобной в работе кюветы, обеспечивающей эффективное уплотнение базисного материала для компенсации его усадки при полимеризации и имеющей возможность адаптации к различным размерам челюстей.

Технология компрессионного варианта изготовления съемных акриловых протезов посредством применения кюветы двойного винтового дожатия.

Для решения поставленной задачи предложена кювета для изготовления зубных протезов, содержащая разборный корпус, состоящий из нижней и верхней частей, состыкованных и сжатых между собой, снабженный отверстиями под выходные литниковые каналы. Кювета выполнена из металлической трубы цилиндрической формы со съемными крышками в каждой из частей с возможностью их поджатия с помощью винтов (болтов) и с толщиной стенок, обеспечивающей стыковку обеих частей с помощью установленных в стенках частей кюветы металлических штифтов, выходные литниковые каналы образованы двумя отводными трубками (одетыми на винты), нижние концы трубок расположены диаметрально в зоне разъема с возможностью установки в создаваемых при выполнении гипсовой формы углублениях, примыкающих к щечным поверхностям репродукции восковой модели, располагаемой в центральной части кюветы, а верхние выступающие над кюветой концы отводных трубок пропущены через отверстия, выполненные в крышке верхней части. Крышка нижней части снабжена ступенчатой вставкой, соосно установленной с возможностью осевого перемещения вверх и давления на гипс, при этом внутренние поверхности кюветы защищены от взаимодействия с гипсом с помощью изоляции (возможно писчей бумагой). Соединение нижней части корпуса кюветы с нижней крышкой с винтами и отверстиями для пластмассовых трубок представляет собой «штамп», т.е. нижнюю часть разъемной 

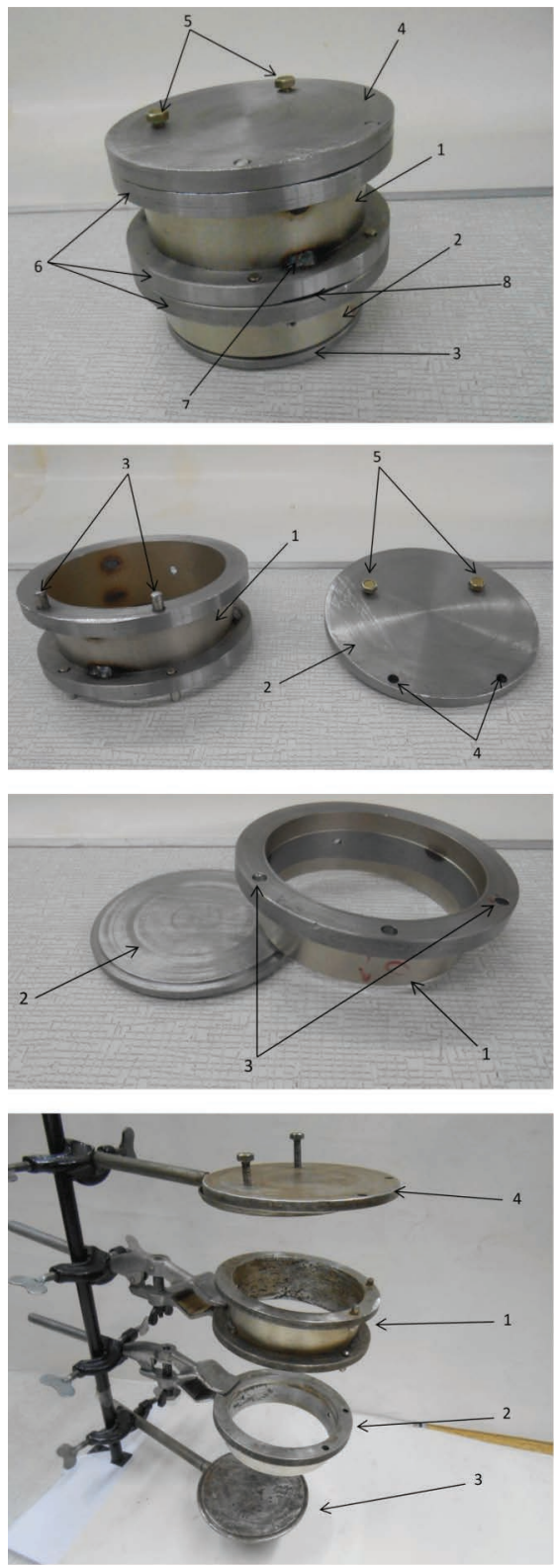

Рис. 4. Кювета двойного винтового дожатия (общий вид в сборе). 1. Нижняя часть корпуса (труба и 2 фланца со штифтовыми отверстиями). 2. Верхняя часть корпуса (труба и 1 фланец с отверстиями). 3. Верхняя крышка со ступенчатой вставкой. 4 . Нижняя крышка с винтами и отверстиями для трубок. 5. Винты для трубок с винтовыми отверстиями в нижней крышке. 6. Фланцы (сваренные с кольцами трубы ступенчатые шайбы со штифтами и отверстиями для точного соединения частей корпуса). 7. Точка соединения фланца и нижней части корпуса (сварка). 8. Линия соединения «штампа) и «контрштампа».

Рис. 5. «Штамп» в разобранном виде (нижняя часть кюветы). 1. Нижняя часть корпуса (труба и 2 фланца со штифтами и отверстиями). 2.Нижняя крышка с закрученными винтами в нарезные отверстия. 3. Штифты в нижнем фланце нижней части корпуса для фиксации нижней крышки. 4. Отверстия в нижней крышке для её фиксации на штифты нижнего фланца нижней части корпуса. 5. Закрученные до упора винты для трубок с винтовыми отверстиями в нижней крышке.

Рис. 6. «Контрштамп» в разобранном виде (верхняя часть кюветы).

1. Верхняя часть корпуса (труба и 1 фланец с отверстиями). 2. Верхняя крышка со ступенчатой вставкой. 3. Отверстия для штифтов во фланще верхней части корпуса.

Рис. 7. Кювета двойного винтового дожатия (общий вид в разобранном состоянии, в правильном соотношении частей перед сборкой). 1. Нижняя часть корпуса (труба и 2 фланца со штифтами и отверстиями). 2. Верхняя часть корпуса (труба и 1 фланец с отверстиями). 3. Верхняя крышка со ступенчатой вставкой. 4. Нижняя крышка с винтами и отверстиями для трубок. 

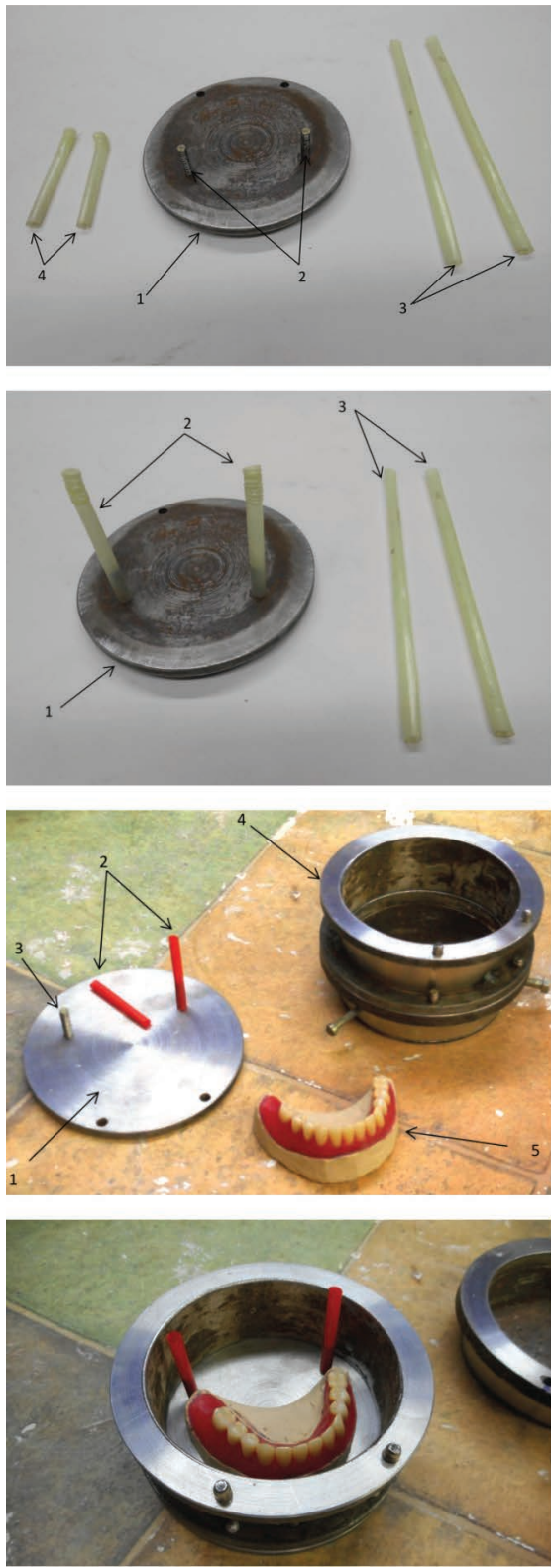

Рис. 8. Подготовка литниковых каналов в «штампе».

1. Нижняя крышка кюветы. 2. Винты для трубок с винтовыми отверстиями в нижней крышке. 3. Части пластмассовых трубок (от коктейлей) для фиксации на винтах, отрезанные по уровню гибкой муфты от прямой основы. 4. Остатки пластмассовых трубок.

Рис. 9. Пластмассовые трубки с муфтами зафиксированы (надеты) на винты нижней крышки кюветы.

1. Нижняя крышка с закрученными до упора винтами. 2. Части пластмассовых трубок (от коктейлей), фиксированные на винтах с гибкими муфтами на свободных конца. 3. Остатки пластмассовых трубок.

Рис. 10. Снятые и накрученные на винты пластмассовые трубки с залитым базисным расплавляющимся воском.

1. Нижняя крышка кюветы с закрученными до упора винтами. 2. Пластмассовые трубки с залитым в них базисным воском (одна уже зафиксирована на винте). 3. Свободный от трубки винт. 4. Общий вид кюветы в сборе без нижней крышки. 5. Восковая композиция полного съемного протеза на гипсовой модели.

Рис. 11. Нижняя крышка кюветы с заполненными воском трубками, зафиксированными на винтах. 

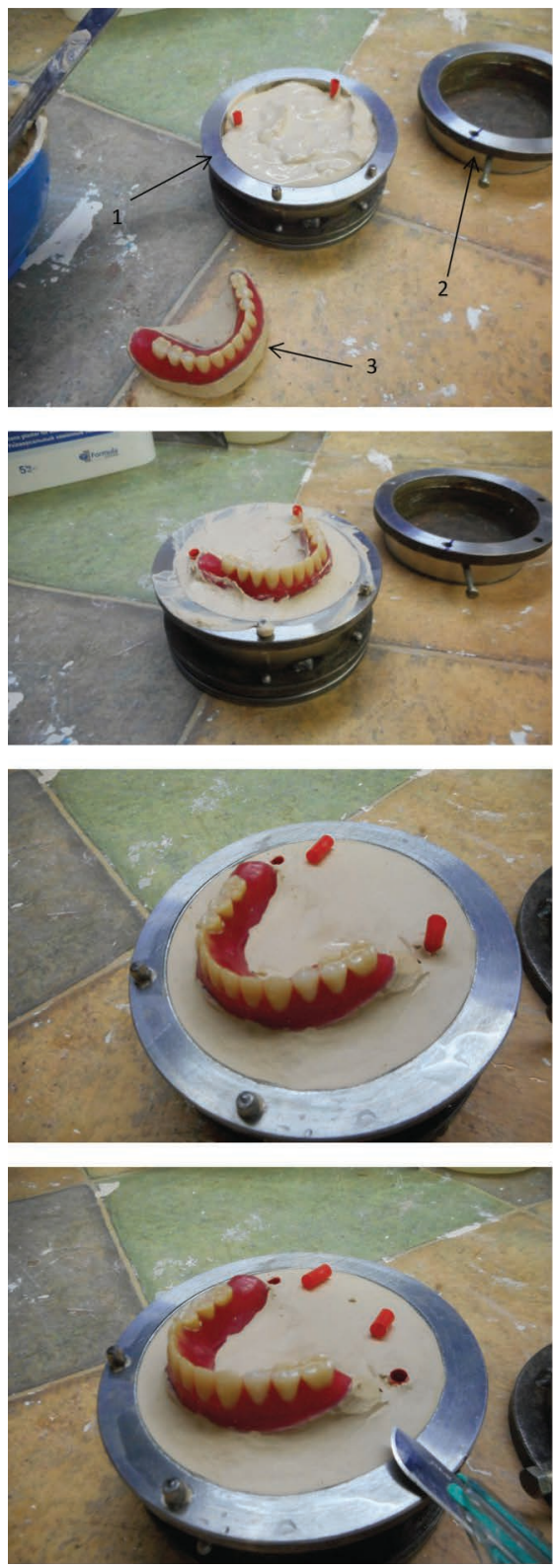

Рис. 12. Заливка гипсом полости «штампа» кюветы.

1. «Штамп» кюветы

2. «Контрштамп» кюветы

3. Гипсовая модель с восковой композицией съемного протеза.

Рис. 13. Гипсовка гипсовой модели с восковой композицией съемного протеза в «штамп» кюветы.

Рис. 14. Выступающие восковые литники над уровнем штампа.

Рис. 15. Уровень восковых литников для восковой петли. 


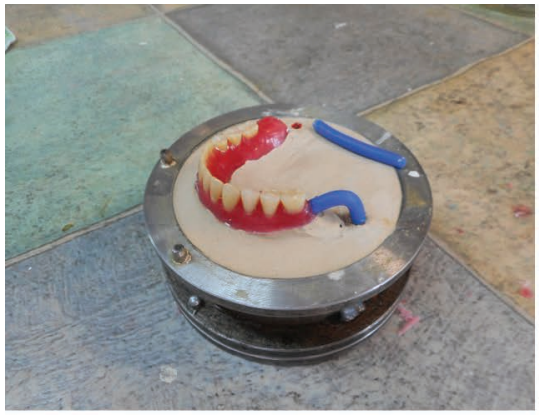

Рис. 16а

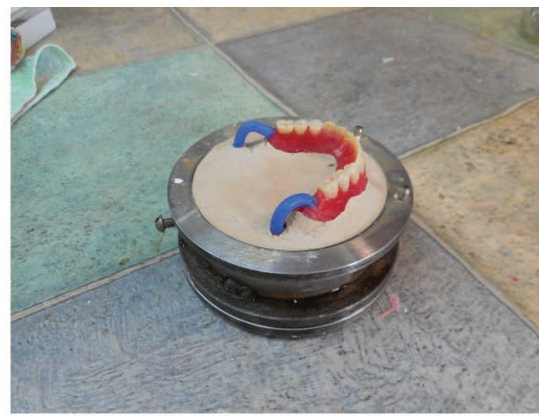

Puc. 16b

Рис. 16. Этапы моделировки восковой петли.

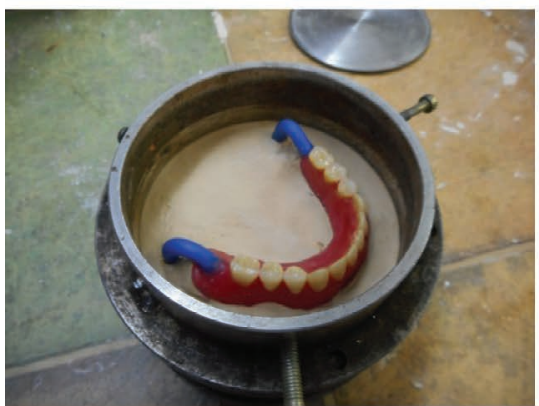

Рис. 17. Соединение «штампа) и «контрштампа» (без крышки).

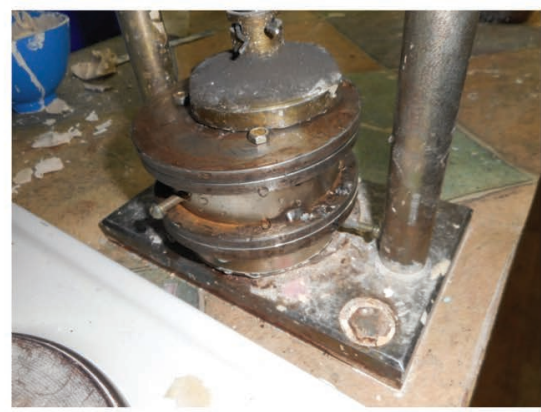

Рис. 18.

Фиксация кюветы под прессом.

пресс-формы, которой и является данная кювета. Планирование взаимного расположения дистальных краёв восковой композиции съемного протеза и трубок на нижней крышке кюветы, в которых в последующем будут располагаться литники, присоединенные к дистальным краям протеза (рис. 4-10). После этого изготавливают литниковые каналы (рис. 11), планируют взаимное расположение дистальных краев восковой композиции съемного протеза и трубок на нижней крышке кюветы в «штампе» кюветы (нижняя крышка+нижняя часть корпуса кюветы) с возвышением над уровнем «штампа» на 5-10 мм (рис. 12, 13), готовят к моделировке соединительной литниковой петли обрезанием до уровня гипса выступающих краев трубок с воском (рис. 14, 15), моделируют соединительную литниковую петлю из синего шнурового литникового воска между дистальными краями восковой композиции съемного протеза и выходами из гипса обрезанных пластмассовых трубок с воском (рис. 16a, b). 
Далее соединяют «штамп» кюветы с «контрштампом» в соответствии штифтов на «штампе» и отверстий на «контрштампе» (до соединения «штампа» кюветы с восковой композицией съемного протеза, гипсом и литниками «штамп» выдержан в прохладной воде до полного насыщения гипса, чтобы в последующем гипс «штампа» отделился от гипса «контрштампа») (рис. 17). После заполнения полости «контрштампа» кюветы и закрытия его верхней крышкой кювету переворачивают и помещают под пресс (рис. 18). Уплотнив гипс и выдавив его излишки под прессом, кювету помещают в так называемый «бюгель», или струбцину, где она удерживается до полного застывания гипса (рис. 19). Кювету кипятят в воде в течении 5-10 минут для размягчения воска (для того, чтобы не загрязнить кювету и модель, расплавленный воск собирают с поверхности воды и раскрывают кювету) (рис. 20), удаляют размягченный воск, промывают «штамп» и «контрштамп» и высушивают последние (рис. 21, 22). Для предупреждения соединения пластмассы базиса с гипсом модели и исключения проникновения воды в пластмассу поверхности «штампа» и «контрштампа» модели покрывают слоем изоляционного лака (рис. 23). Затем традиционным способом готовят и прессуют пластмассовое «тесто» (рис. 24, 25). Особенности: излишки пластмассы выдавливаются не только между «штампом» и «контрштампом», но и через литниковые ходы (трубки) в нижней крышке, поэтому возникновение грата исключено! После прессования кювету помещают в «бюгель» (струбцину) для плотного удержания частей кюветы (рис. 25). Особенности: удалив с поверхности выхода трубок на нижней крышке кюветы излишки мягкого «теста» пластмассы, в трубки, с помощью специального ключа, вкрутив винты до минимального упора в пластмассу, но не в крышку кюветы, до упора (первое винтовое дожатие пластмассы). Пластмассу полимеризуют на «водяной бане»»: кювету в бюгеле (струбцине) помещают в воду комнатной температуры, доводят ее до кипения и в течении 1 часа кипятят (рис. 26). В связи с обязательной усадкой пластмассы, во время начала кипячения выполняют второе винтовое дожатие пластмассы двумя или тремя оборотами винтов до упора в крышку, вынув кювету с бюгелем из воды на 1-2 минуты. После окончания периода полимеризации (2 часа) с помощью специального ключа винты выкручивают из отверстий в нижней крышке кюветы (рис. 27), вынимают кювету из «бюгеля» (струбцины) и осторожно (постукиванием молоточка) отделяют «штамп» кюветы от «контрштампа» (рис. 28-30). 


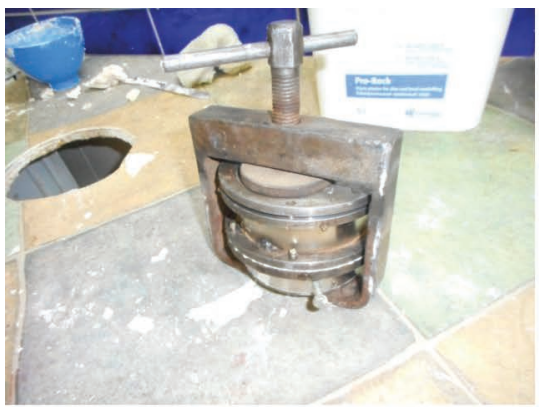

Рис. 19.

Кювета фиксирована в бюгеле.

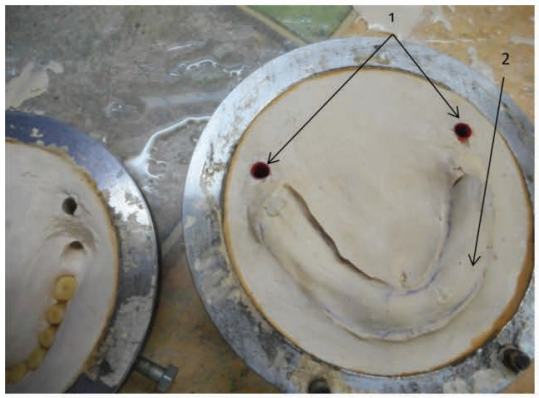

Рис. 21. Гипсовые «контрштамп» (слева) и «штамп» (справа) после раскрытия кюветы и удаления размягченного воска.

1 - отверстия литников с основой из пластмассовых трубок, 2 - гиповая модель протезного ложа.

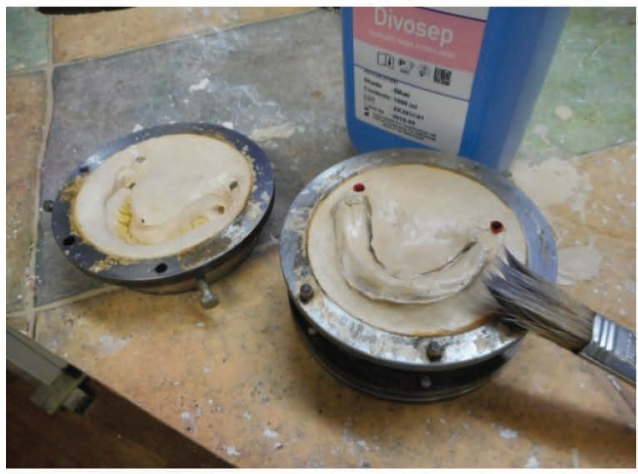

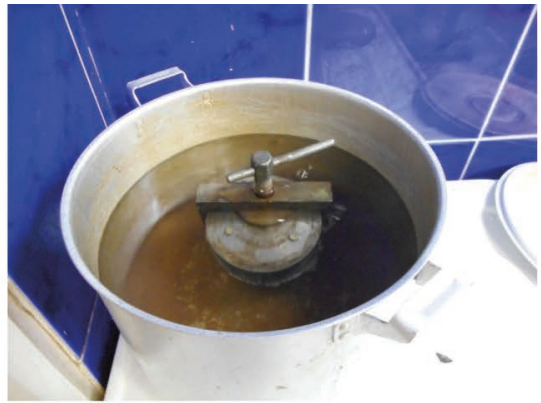

Рис. 20.

Кювета после процесса кипячения.

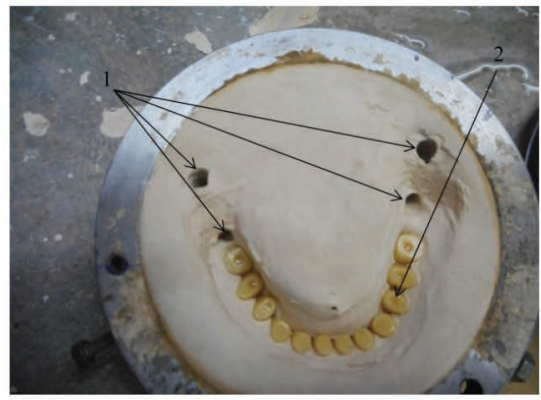

Рис. 22. Пластмассовые зубы съемного протеза (обнажены части зубов, которые были погружены в воск). 1 - литниковые отвертстия, 2 - пластмассовые зубы.
Рис. 23. «Штамп» и «контрштапм» после покрытия изоляционным лаком. 


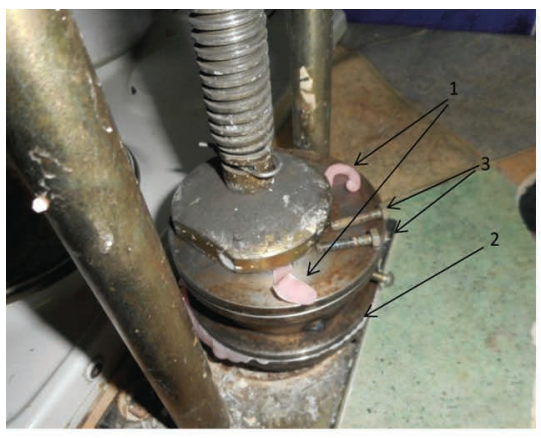

1 - выдавленные излишки пластмассы через литниковые ходы (трубки) в нижней крышке кюветы.

2 - выдавленные излишки пластмассы между «штампом» и «контрштампом» (традиционный вариант).

3 - выкрученные винты из отверстий крышки.

Рис. 24. Паковка пластмассового «теста» под прессом.

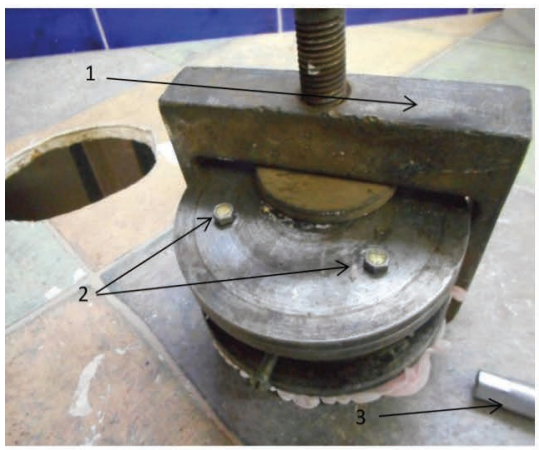

1 - бюгель (струбцина).

2 - вкрученные винты.

3 - специальный (торцевой) ключ для винтов.

Рис. 25. Кювета после первого винтового дожатия.

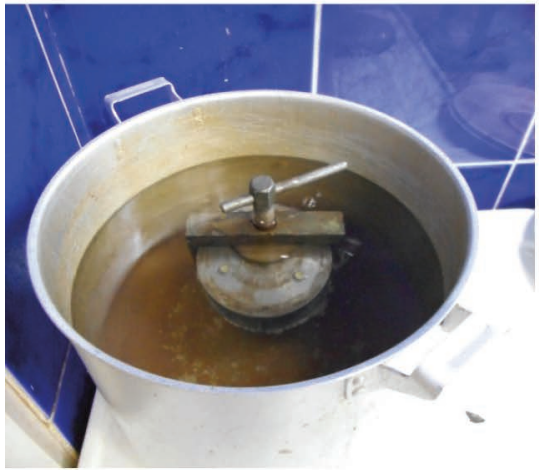

Рис. 26. Кювета подготовлена для полимеризации на «водяной бане».

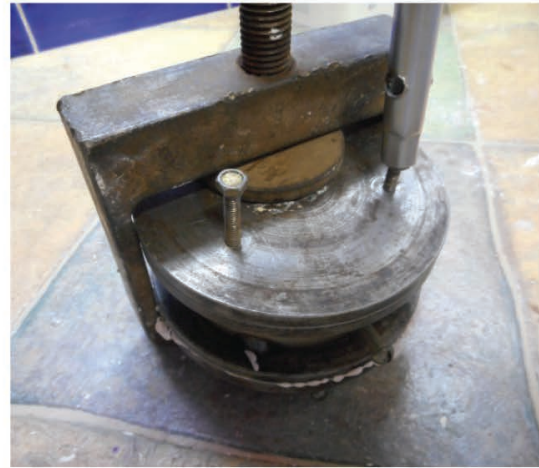

Рис. 27. Удаление винтов

из кюветы с помощью торцевого ключа после полимеризации пластмассы. 

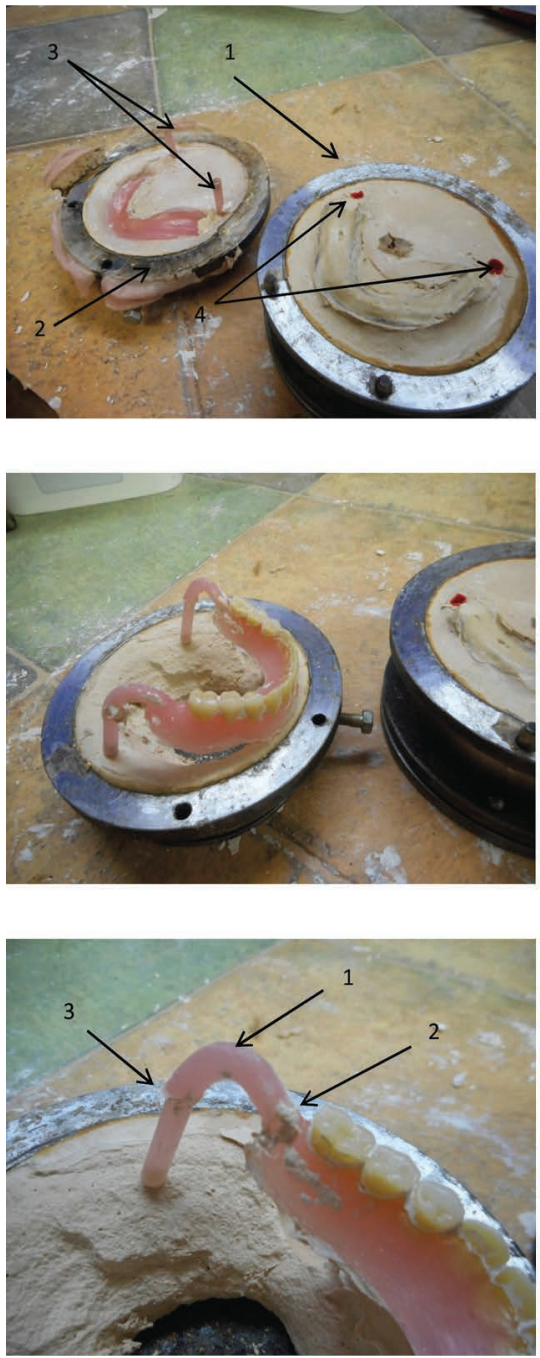

Рис. 28. «Штамп» (справа) и «контрштамп» (слева) разделены после полимеризации пластмассы.

1 - «Штамп» кюветы

2 - «Контрштамп〉 кюветы

3 - извлеченные пластмассовые литники из трубочных отверстий в «штампе» кюветы. 4 - трубочные отверстия в «штампе»

Pис. 29. Частично освобожденный от гипса (после полимеризации) съемный протез с пластмассовыми литниковыми петлями.

Для оценки содержания остаточного мономера (метилметакрилата) в стоматологической пластмассе использовали метод экстракции (явление миграции мономера из пластмассы при взаимном контакте). Использовали образцы стоматологических базисных акриловых пластмасс марок: протакрил, вертекс, бесцветная, этакрил и фторакс в виде брусков тра- 
пецевидной формы с размером сечения 5-6×4-5 мм; длиной 50-60 мм, весом 5-9 г. Образцы получали серийно в кювете двойного винтового дожатия с одинаковыми условиями полимеризации по представленной методике. Предварительно взвешенные образцы, каждый в отдельности, помещали в стеклянные пробирки объемом 50 мл. В качестве растворителя использовали $10 \%$ раствор этилового спирта. Методом спектрофотометрии определяли количество остаточного мономера через 5, 10, 17, 19, 22 суток в каждой пробирке. Пористость вышеуказанных образцов изучали путем электронно-микроскопического сканирования сколотых поверхностей, напыленых платиной в установке вакуумного магнетронного напыления K575XD (Emitech, Великобритания). Все исследования выполняли на базе Института химии и химической технологии Сибирского отделения РАН под руководством д.Х.н. профессора А.И. Рубайло и к.т.н. А.М. Жижаева.

\section{Результаты исследования}

Основываясь на литературных данных о токсилогических нормах содержания метилметакрилата в стоматологических пластмассах (последний не должен превышать 0,01 мк $^{\mathrm{T}}$ /мл воде и $0,25 \mathrm{MK}^{\mathrm{r}} / \mathrm{M}$ в в стоматологических экстрактах) [1-2] установлено, что содержание остаточного количества мономера (MМА) в исследуемых образцах базисных акриловых пластмасс в среднем менялось в следующих пределах: протакрил от 0,0009\% до 0,1\% (изменение в 10 раз); вертекс от $0,007 \%$ до 0,05\% (изменение в 7 раз); бесцветная от $0,004 \%$ до $0,008 \%$ (изменение в 2 раза); этакрил от $0,05 \%$ до $0,02 \%$ (изменение в 4 раза); фторакс от $0,004 \%$ до $0,015 \%$ (изменение в 4 раза) (результаты в весовых процентах).

Что касается пористости полученных образцов, то они имели достаточно плотную структуру (в сравнении с традиционно изготовленными). Пористость по основной поверхности для пластмасс «Вертекс», «Протакрил», «Фторакс» и «Этакрил» не превышала тысячных долей процента. Исключение составила бесцветная пластмасса, имеющая относительно высокую пористость 3,9\%.

\section{Заключение}

Предложенная кювета двойного винтового дожатия позволяет сохранять заданные размеры (вследствие отсутствия грата), значительно уменьшить токсичность и пористость пластмасс и, как следствие, повысить прочностные свойства изготавливаемых протезов. 


\section{Список литературы}

1. Ворожко А.А. Влияние гигиенического состояния полости рта на степень аллергических проявлений при использовании базисных акриловых пластмасс / А.А. Ворожко, В.А. Клемин // Труды IX международной научно-практической конференции, посвященной 140-летию Белгородского государственного национального исследовательского университета. Белгород, 2016. С. 73-75.

2. Временные параметры клинических этапов при изготовлении частичных съемных пластиночных протезов / С.И. Донских, Ю.В. Красникова, А.Ю. Малый и др. // Труды IX международной научно-практической конференции, посвященной 140-летию Белгородского государственного национального исследовательского университета. Белгород, 2016. С. 137-139.

3. Выявление пористости акриловых стоматологических пластмасс с помощью сканирующей электронной зондовой микроскопии (экспериментальное исследование) / Ю.В. Чижов, Л.Е. Маскадынов, Е.В. Мазурова и др. // Институт стоматологии. 2016. №3(72). С. 87-89.

4. ГОСТ 31572-2012 «Материалы полимерные для базисов зубных протезов. Технические требования. Методы испытаний».

5. Желудев С.Е. Способы лечения непереносимости съемных зубных протезов / С.Е. Желудев, В.П. Олешко, В.И. Баньков // Панорама ортопедической стоматологии. 2003. №3. С. 28-34.

6. Каливраджиян Э.С. Основы технологии зубного протезирования: учебник для медицинских училищ и колледжей / Э.С. Каливраджиян. М: МЕДпресс-информ, 2016. Т.2. 389 с.

7. Контроль содержания свободных акриловых мономеров в отечественных базисных пластмассах съемных зубных протезов (экспериментальное исследование) / Ю.В. Чижов, Л.Е. Маскадынов, Е.Н. Маскадынов и др. // Сибирское медицинское обозрение. 2015. №6 (96). С. 69-73.

8. Лабораторное обоснование применения базисных материалов отечественного производства фирмы «Владмива» / Ю.А. Меняйло, А.А. Копытов, А.В. Цимбалистов и др. // Труды IX международной научно-практической конференции, посвященной 140-летию Белгородского государственного национального исследовательского университета. 2016. С. 280-282.

9. Огородников М.Ю. Новые базисные материалы на основе полиуретана для съемных зубных протезов - исследование химической и биологической безопасности / М.Ю. Огородников // Институт стоматологии. 2004. №1. С. 87-90.

10. Ортопедическая стоматология. Прикладное материаловедение: учебник / В.Н. Трезубов, Л.М. Мешнев, Е.Н. Жулев и др. М.: МЕДдпресс-информ, 2011. $373 \mathrm{c}$. 
11. Ортопедическая стоматология. Технология лечебных и профилактических аппаратов: учебник / В.Н. Трезубов, Л.М. Мешнев, Н.Ю. Незнанова и др. М.: МЕДпресс-информ, 2016. 320 с.

12. Разработка пластмасс для базисов съемных протезов с учетом необходимости снижения уровня наркотизма в Российской Федерации / Б.В. Трифонов, Ю.А. Миняйло, А.А. Копытов и др. // Труды IX международной научно-практической конференции, посвященной 140-летию Белгородского государственного национального исследовательского университета. Белгород, 2016. С. 419-421.

13. Руководство по ортопедической стоматологии. Протезирование при полном отсутствии зубов / И.Ю. Лебеденко, Э.С. Каливраджиян, Т.И. Ибрагимов и др. М.: ООО «Медицинская пресса», 2008. 372 с.

14. Смирнов Б.А. Зуботехническое дело в стоматологии: учебник для медицинских училищ и колледжей / Б.А. Смирнов, А.С. Щербаков. М: ГЭОТАР-Медиа, 2016. 336 с.

15. Сравнительная характеристика акриловых базисных пластмасс / С.Н. Поздняков, А.В. Цимбалистов, В.В. Чуев и др. // Институт стоматологии. 2016. №4. C. 98-99.

16. Comparison of the dimensional accuracy of injectionmolded denture base materials to that of conrentional pressurepark acrjlic resin / A. Parvizi, T. Zindguist, R. Schneide et al. // J. Prosthodont. 2004. V.13, №2, pp. 89-98.

17. Rutner J.W. Flexural properties und surfaxe finishing ofacetal resin denture claps / J.W. Rutner, M. Rodford // J. Prosthodont. 1999. V.8, №3, pp. 188-195.

\section{References}

1. Vorozhko A.A., Klemin V.A. Trudy IX mezhdunarodnoj nauchno-prakticheskoj konferentsii, posvjaschennoj 140-letiju Belgorodskogo gosudarstvennogo natsional'nogo issledovatel'skogo universiteta [Proceedings of the IX international scientific and practical conference dedicated to the 140th anniversary of the Belgorod state national research University]. Belgorod, 2016, pp. 73-75.

2. Donskih S.I., Krasnikova Ju.V., Malyj A.Ju. et al. Trudy IX mezhdunarodnoj nauchno-prakticheskoj konferentsii, posvjaschennoj 140-letiju Belgorodskogo gosudarstvennogo natsional'nogo issledovatel'skogo universiteta [Proceedings of the IX international scientific and practical conference dedicated to the 140th anniversary of the Belgorod state national research University]. Belgorod, 2016, pp. 137-139.

3. Chizhov Ju.V., Maskadynov L.E., Mazurova E.V. et al. Institut stomatologii. 2016. №3(72), pp. 87-89. 
4. GOST 31572-2012 «Materialy polimernye dlja bazisov zubnyh protezov. Tehnicheskie trebovanija. Metody ispytanij».

5. Zheludev S.E., Oleshko V.P., Ban'kov V.I. Panorama ortopedicheskoj stomatologii. 2003. №3, pp. 28-34.

6. Kalivradzhijan E.S. Osnovy tehnologii zubnogo protezirovanija: uchebnik dlja meditsinskih uchilisch $i$ kolledzhej [Fundamentals of dental prosthetics technology: textbook for medical schools and colleges]. M: MEDpress-inform, 2016. T.2. 389 p.

7. Chizhov Ju.V., Maskadynov L.E., Maskadynov E.N. et al. Sibirskoe meditsinskoe obozrenie. 2015. №6 (96), pp. 69-73.

8. Menjajlo Ju.A., Kopytov A.A., Tsimbalistov A.V. et al. Trudy IX mezhdunarodnoj nauchno-prakticheskoj konferentsii, posvjaschennoj 140-letiju Belgorodskogo gosudarstvennogo natsional'nogo issledovatel'skogo universiteta [Proceedings of the IX international scientific and practical conference dedicated to the 140th anniversary of the Belgorod state national research University]. Belgorod, 2016, pp. 280-282.

9. Ogorodnikov M. Ju. Institut stomatologii. 2004. №1, pp. 87-90.

10. Trezubov V.N., Meshnev L.M., Zhulev E.N. et al. Ortopedicheskaja stomatologija. Prikladnoe materialovedenie: uchebnik [Prosthetic dentistry. Applied materials science: textbook]. M.: MEDdpress-inform, 2011. 373 p.

11. Trezubov V.N., Meshnev L.M., Neznanova N.Ju. et al. Ortopedicheskaja stomatologija. Tehnologija lechebnyh i profilak-ticheskih apparatov: uchebnik [Prosthetic dentistry. Technology of medical and preventive devices: textbook]. M.: MEDdpress-inform, 2016. 320 p.

12. Trezubov V.N., Menjajlo Ju.A., Kopytov A.A. et al. Trudy IX mezhdunarodnoj nauchno-prakticheskoj konferentsii, posvjaschennoj 140-letiju Belgorodskogo gosudarstvennogo natsional'nogo issledovatel'skogo universiteta [Proceedings of the IX international scientific and practical conference dedicated to the 140th anniversary of the Belgorod state national research University]. Belgorod, 2016, pp. 419-421.

13. Lebedenko I.Ju., Kalivradzhijan E.S., Ibragimov T.I. et al. Rukovodstvo po ortopedicheskoj stomatologii. Protezirovanie pri polnom otsutstvii zubov [Guide to orthopaedic dentistry. Prosthetics in the complete absence of teeth]. M.: OOO «Meditsinskaja pressa», 2008. $372 \mathrm{p}$.

14. Smirnov B.A., Scherbakov A.S. Zubotehnicheskoe delo v stomatologii: uchebnik dlja meditsinskih uchilisch i kolledzhej [Dental engineering: textbook for medical schools and colleges]. M: G'EOTAR-Media, 2016. 336 p.

15. Pozdnjakov S.N., Tsimbalistov A.V., Chuev V.V. et al. Institut stomatologii. 2016. №4, pp. 98-99. 
16. Parvizi A., Zindguist T., Schneide R. et al. Comparison of the dimensional accuracy of injectionmolded denture base materials to that of conrentional pressurepark acrjlic resin. J. Prosthodont. 2004. V.13, №2, pp. 89-98.

17. Rutner W., Rodford M. Flexural properties und surfaxe finishing ofacetal resin denture claps. J. Prosthodont. 1999. V.8, №3, pp. 188-195.

\section{ДАННЫЕ ОБ АВТОРАХ}

Чижов Юрий Васильевич, доктор медицинских наук, профессор

Красноярский государственный медииинский университет им. проф. В.Ф. Войно-Ясенеикого

ул. Партизана Железняка, 1, г. Красноярск, 660022, Российская Федераичи

gullever@list.ru

Радкевич Андрей Анатольевич, доктор медицинских наук

Научно-исследовательский институт медичинских проблем Севера ул. Партизана Железняка, 32, г. Красноярск, 660022, Российская Федерация

radkevich.andrey@yandex.ru

Маскадынов Лев Евгеньевич, врач-ортопед-стоматолог

СП «Вивап-Дент»

пр. Дружбы народов, 23, г. Абакан, Республика Хакассия, 665017, Российская Федерация

Vivapdent@rambler.ru

Казанцева Тамара Владимировна, кандидат медицинских наук Красноярский государственный медицинский университет им. проф. В.Ф. Войно-Ясенецкого

ул. Партизана Железняка, 1, г. Красноярск, 660022, Российская Федерачия

Kazancevatv@onkolog24.ru

\section{DATA ABOUT THE AUTHORS}

Radkevich Andrey Anatolevich, MD

Scientific Research Institute of Medical Problems of the North 3g, Partizan Zheleznyak Str., Krasnoyarsk, 660022, Russian Federation radkevich.andrey@yandex.ru 
Chizhov Yuriy Vasilyevich, MD

Krasnoyarsk State Medical University

1, Partizan Zheleznyak Str., Krasnoyarsk, 660022, Russian Federation gullever@list.ru

Muscadine Lev Evgenievich, doctor-orthopedist-dentist

$S P$ «vivap-dent»

peoples Friendship Ave., 23, Abakan, Republic of Khakassia, 665017, Russian Federation

Vivapdent@rambler.ru

Kazantseva Tamara Vladimirovna, Candidate of Medical Sciences

Krasnoyarsk State Medical University

1, Partizan Zheleznyak Str., Krasnoyarsk, 660022, Russian Federation Kazancevatv@onkolog24.ru 